\title{
Jan Pisuliński
}

https://orcid.org/0000-0002-9302-5631

Uniwersytet Rzeszowski

\section{Koncepcje federacyjne w II Rzeczypospolitej}

Zarys treści: Artykuł przedstawia koncepcje federacyjne powstałe w okresie II Rzeczypospolitej, ich założenia, cele i zasady oraz ich uzasadnienie. Krótko omawia środowiska polityczne, które je formowały. Dominowały środowiska lewicowe, szczególnie aktywni na tym polu byli socjaliści. Odwoływali się do tradycji jagiellońskiej i Rzeczypospolitej Obojga Narodów. Forsowali ideę federacji trialistycznej składającej się z Polski, Litwy i Białorusi. Rzadziej dołączano do niej Ukrainę i inne państwa bałtyckie, Łotwę i Estonię. Koncepcje federacyjne po traktacie ryskim w 1921 r. wysuwano już tylko sporadycznie.

Outline of content: The article presents federation concepts formulated in the Second Polish Republic, their origins, goals, principles, and justification. It briefly discusses the political circles in which they were thought out. Left-wing groups predominated, with socialists being particularly active in this field. Their authors referred to the Jagiellonian tradition and the Polish-Lithuanian Commonwealth, and promoted the idea of a trialist federation consisting of Poland, Lithuania, and Belarus. Less frequently, the concepts included Ukraine and other Baltic states, such as Latvia and Estonia. After the Riga Treaty of 1921, federation concepts were defined only sporadically.

Slowa kluczowe: federacja, II Rzeczpospolita, Józef Piłsudski, Litwa, Białoruś, Ukraina

Keywords: federation, Second Polish Republic, Piłsudski, Lithuania, Belarus, Ukraine

Wizje federacyjne można rozpatrywać albo szerzej, obejmując koncepcje dotyczące całej Europy, albo w węższym zakresie, jak Karol Grünberg czy Krzysztof Grygajtis, ograniczając się do federacji Polski z sąsiednimi narodami ${ }^{1}$. W niniejszym

1 Ten ostatni analizował myśl federacyjną w tym węższym ujęciu, „jako skonkretyzowany wyraz dążeń restytucyjnych, stanowiących punkt wyjścia dla odbudowy Rzeczypospolitej Obojga Narodów”. K. Grygajtis, Polskie idee federacyjne i ich realizacja w XIX i XX wieku, Częstochowa 2001, s. 6. Podobnie: M. Kornat, Z projektów federacyjnych w polskiej myśli politycznej (1917-1921), 
tekście w ślad za wspomnianymi autorami skoncentruję się na tym ostatnim ujęciu. $\mathrm{Z}$ uwagi na obszerność zagadnienia starałem się ująć go maksymalnie syntetycznie, skupiając się na treści idei federacyjnych i środowiskach je propagujących. $\mathrm{Z}$ tego samego względu zasygnalizowałem tylko recepcję koncepcji federacyjnych w społeczeństwie polskim, jak i wśród narodów, które miały wejść w skład federacji: Litwinów, Białorusinów czy Ukraińców. Projekty integracji całego kontynentu europejskiego, w tym rozwiązania federalistyczne, wymagają osobnego omówienia, przekraczającego ramy pracy.

Prezentowane zagadnienie było już przedmiotem refleksji naukowej, ale dotyczyło to zwykle projektów powstałych przed odzyskaniem niepodległości ${ }^{2}$. Powodowane to było zapewne przekonaniem, że koncepcje powstałe w międzywojniu przynajmniej częściowo powielały wcześniejsze rozwiązania, a ponadto po krótkim okresie wręcz wysypu projektów federacyjnych w 1919 r. zainteresowanie nimi wygasło i już doń nie powracano ${ }^{3}$. Omawiane w tekście koncepcje na ogół badano w węższym zakresie, w myśli politycznej poszczególnych działaczy czy partii politycznych ${ }^{4}$. Szczególne miejsce w tych analizach zajmują poglądy Józefa

w: O ziemię nasza, nie waszą. Ideowe aspekty procesów narodowotwórczych w Europie Środkowej $i$ Wschodniej, red. Ł. Adamski, Warszawa 2017, s. 366.

2 Zob. np.: W. Bączkowski, U źródeł polskiej idei federacyjnej, Jerozolima 1945; K. Grünberg, Polskie koncepcje federalistyczne 1864-1918, Warszawa 1971; W. Bokajło, Historyczne tło polskiego federalizmu, w: Federalizm. Teorie i koncepcje, red. W. Bokajło, Wrocław 1998, s. 175-201; P.S. Wandycz, Polscy prekursorzy federalizmu, w: idem, O federalizmie i emigracji. Reminiscencje o rzeczach istotnych i błahych, Lublin 2003, s. 97-113; K. Daszyk, Idea Europy wolnych i zjednoczonych narodów w polskiej myśli politycznej XIX w., w: Europa unii i federacji. Idea jedności narodów i państw od średniowiecza do czasów wspótczesnych, red. K. Ślusarek, Kraków 2004, s. 231-258; J. Wojtasik, Tradycje unijne w polskiej myśli politycznej do 1918 roku, w: Rzeczpospolita Obojga Narodów i jej tradycje. Studia i szkice, red. M. Wagner, J. Wojtasik, Siedlce 2004, s. 197-210; M. Maciejewski, Wspólna Europa w polskich koncepcjach politycznych czasów nowożytnych, w: Dialog idei w Europie w XX i XXI wieku, red. E. Ponczek, A. Sepkowski, Toruń 2011, s. 95-122; B. Kubis, Polska myśl polityczna wobec idei integrowania Europy $w$ drugiej połowie XIX wieku i początkach XX, w: Europejskie inspiracje myśli politycznej w Polsce od XIX do XXI wieku, red. E. Maj, A. Dawidowicz, Ł. Lewkowicz, A. Szwed, Lublin 2013, s. 17-30; J. Juchnowski, S. Juchnowski, Koncepcje unijno-federalistyczne w polskiej myśli politycznej na tle integracyjnych idei europejskich, „Społeczeństwo i Polityka” (2019), nr 3 (60), s. 89-114.

3 Por. J. Faryś, Między Moskwa a Berlinem. Wizje polskiej polityki zagranicznej 1918-1939, Szczecin-Warszawa 2019, s. 78. Marek Kornat za apogeum formułowania projektów federacyjnych uważa lata 1917-1921. M. Kornat, op. cit., s. 366.

${ }^{4}$ Zob. np.: M. Śliwa, Federalizm i autonomia narodowościowa w myśli Mieczysława Niedziałkowskiego, "Czasopismo Prawno-Historyczne” 30 (1978), z. 2, s. 139-153; J. Juchnowski, Federalizm i integracja europejska $w$ myśli politycznej socjalistów polskich (1922-1939), w: Federalizm..., s. 202-213; idem, Federalizm w polskiej myśli politycznej XX wieku, w: Polacy-Polska-Europa. Interpretacje idei politycznych, red. T. Godlewski, W. Jurkiewicz, Bydgoszcz 2002, s. 209-222; Ł. Zweiffel, Państwa bałtyckie wobec koncepcji federacyjnej PPS, „Rocznik Wschodni” (2004), nr 10, s. 291-295; idem, „O program polski na Wschodzie” - koncepcja federacyjna w publicystyce socjalistycznej lat 1919-1920, „Rocznik Wschodni” (2006/2007), nr 12, s. 232-236; A. Wojtaszak, Koncepcje federacyjne Leona Wasilewskiego, „Nowa Krytyka” (2016), nr 37, s. 247-264; 
Piłsudskiego. Dzieje się tak zarówno dlatego, że był liderem obozu belwederskiego, z którym wiązano omawianą ideę, jak i z powodu toczonych do dzisiaj sporów, na ile rzeczywiście jej hołdował ${ }^{5}$. Analizowano je również w szerszych ramach omawiania polityki wschodniej odrodzonego państwa polskiego w pierwszych latach niepodległości ${ }^{6}$.

Podjęcie tego tematu wiąże się więc $\mathrm{z}$ odpowiedzią na pytanie, czy i na ile zmiana sytuacji politycznej, przede wszystkim odrodzenie państwa polskiego oraz chaos powstały po upadku caratu i w konsekwencji pojawienie się mniej lub bardziej trwałych tworów państwowych pomiędzy Polską a Rosją, wpłynęła na modyfikacje wizji formułowanych w poprzednim okresie? Trzeba jednak od razu zastrzec, że siłą rzeczy w tak krótkim tekście możliwe jest jedynie zarysowanie głównych nurtów federalistycznego myślenia.

Zacząć należałoby od wspomnianego wyżej tła i kontekstu samej idei. W pamięci historycznej Polaków wciąż tkwiła I Rzeczpospolita z okresu największej świetności. Stąd zrodziło się przekonanie sformułowane najdobitniej przez Piłsudskiego, że Polska będzie wielka albo nie będzie jej wcale. Wielu Polaków życzyło sobie odbudowy państwa w granicach sprzed $1772 \mathrm{r}$. Był to też podstawowy punkt odniesienia dla polskich elit, nawet jeśli nie wierzyły już w celowość i powodzenie prób przywrócenia takiego stanu rzeczy ${ }^{7}$. Projekty federacyjne stanowiły też przede wszystkim odpowiedź na zróżnicowanie etniczne tzw. Kresów Wschodnich, gdzie Polacy byli wprawdzie dominującą politycznie i społecznie, ale jednak mniejszością. Wynikały z dostrzeżenia rosnącej świadomości narodowej Białorusinów Litwinów i Ukraińców. Warto zauważyć, że nikt nie proponował takiego rozwiązania w odniesieniu do terenów Pomorza, Warmii i Mazur, Wielkopolski czy Śląska.

Г. Корольов, Федеративні проекти в иентрально-східній Європі від ідеологічної утопії до реальної політики (1815-1921 рр.), Київ 2019, с. 216-240.

5 M.K. Dziewanowski, Joseph Piłsudski. A European Federalist, 1918-1922, Stanford 1969; J. Cisek, Kilka uwag o myśli federacyjnej Józefa Piłsudskiego, w: Międzymorze. Polska i kraje Europy Środkowo-Wschodniej XIX-XX wiek, Warszawa 1995, s. 91-100; P. Hauser, Federacyjna wizja Rzeczypospolitej w poglądach Józefa Piłsudskiego i próba jej urzeczywistnienia w latach 1918-1921, w: Polska i Ukraina. Sojusz z 1920 roku i jego następstwa, red. Z. Karpus, W. Rezmer, E. Wiszka, Toruń 1997; J. Pisuliński, Czy Piłsudski był federalistą? - dylematy polskiej historiografii, „Biuletyn Ukrainoznawczy" (2005), nr 11, s. 111-126; Z. Zaporowski, Federalizm Józefa Piłsudskiego (1918-1922), w: Świat wokót Rzeczypospolitej. Problematyka zagraniczna w polskiej myśli politycznej w pierwszej połowie XX wieku, red. W. Paruch, K. Trembicka, Lublin 2007, s. 179-187; P.S. Wandycz, Piłsudski a federalizm, „Rocznik Instytutu Europy Środkowo-Wschodniej” 10 (2012), z. 4, s. 45-54; W. Łysek, The Federal Idea in Poland in the Interwar Period: Idealism or Pragmatism?, „Politeja” (2017), nr 6 (51), s. 95-116.

${ }^{6}$ Zob. np.: J. Lewandowski, Federalizm. Litwa i Białoruś w polityce obozu belwederskiego (XI 1918 IV 1920), Warszawa 1962; A. Deruga, Polityka wschodnia Polski wobec ziem Litwy, Białorusi i Ukrainy (1918-1919), Warszawa 1969; A. Nowak, Polska i trzy Rosje. Studium polityki wschodniej Józefa Piłsudskiego (do kwietnia 1920), Kraków 2001; P. Okulewicz, Koncepcja „Międzymorza” w myśli i praktyce politycznej obozu Józefa Piłsudskiego w latach 1918-1926, Poznań 2001.

7 R. Wapiński, Świadomość polityczna w Drugiej Rzeczypospolitej, Łódź 1989, s. 156-198. 
Same idee federacyjne swoimi korzeniami tkwiły w szeroko rozumianej tradycji jagiellońskiej, w pamięci unii polsko-litewskiej czy ugody hadziackiej ${ }^{8}$. Roman Wapiński sądził jednak, że większy wpływ miało raczej świeże galicyjskie doświadczenie funkcjonowania w wieloetnicznej, względnie liberalnej monarchii austro-węgierskiej ${ }^{9}$. Ponadto powstały po upadku caratu chaos na wschodzie Europy sprzyjał formułowaniu nawet najbardziej śmiałych wizji, które jeszcze rok wcześniej trudno było sobie nawet wyobrazić. Stąd obserwowany od 1917 r. renesans idei federacyjnych ${ }^{10}$.

Idee te najczęściej łączy się ze środowiskami tzw. lewicy niepodległościowej (przede wszystkim Polskiej Partii Socjalistycznej (PPS) i Polskiego Stronnictwa Ludowego (PSL) „Wyzwolenie” oraz mniejszych ugrupowań o charakterze centrolewicowym, jak np. PSL-Lewica czy efemeryczne Stronnictwo Polskiej Polityki Demokratycznej). Wchodziły one w skład tzw. obozu belwederskiego, do którego zaliczano też lewicę Polskiej Organizacji Wojskowej, byłych legionistów, kręgi II Oddziału Sztabu Generalnego Wojska Polskiego (wywiadu), tygodnika "Rząd i Wojsko" (redaktor naczelny Andrzej Strug, Adam Skwarczyński, Tadeusz Hołówko, Jan Pohoski, Wincenty Rzymowski, Melchior Wańkowicz), publicystów „Gazety Polskiej”"1. Najkrócej ujmując, środowiska te największe zagrożenie widziały $\mathrm{w}$ imperializmie rosyjskim. Przekonywano, że każda Rosja będzie dążyła do zamknięcia Polaków w granicach etnograficznych, a być może nawet ponownie ją ujarzmi ${ }^{12}$. Federacja miała być zaporą przeciwko niej. Jeszcze w listopadzie 1918 r. powstał w Warszawie Komitet ds. Wschodnich, z udziałem m.in. Leona Abramowicza, Tytusa Filipowicza, Marcelego Handelsmana, Witolda Kamienieckiego, Aleksandra Prystora, Wacława Sieroszewskiego, Błażeja Stolarskiego. Byli oni zwolennikami odbudowy Wielkiego Księstwa Litewskiego sfederowanego z Polską. Rozmawiano w tej sprawie z delegacjami białoruskimi ${ }^{13}$.

8 B. Miedziński, Polityka wschodnia Piłsudskiego, „Zeszyty Historyczne” (1975), z. 31, s. 6-26; K. Grygajtis, op. cit., s. 6; M. Kornat, op. cit., s. 386. Aleksy Deruga i Józef Lewandowski podnosili też wpływ niemieckich koncepcji Mitteleuropy, tworzenia tzw. Randstatten. A. Deruga, O federalizmie i polityce wschodniej obozu belwederskiego, „Przegląd Historyczny” (1964), z. 2, s. 319. Mieczysław Niedziałkowski widział genezę federalizmu w ruchu tzw. krajowców (zwolenników wskrzeszenia Wielkiego Księstwa Litewskiego), formułującym swoje koncepcje po 1905 r. m.in. na łamach „Przeglądu Wileńskiego”, „Głosu Polskiego” czy „Kuriera Krajowego”. M. Niedziałkowski, O polski program na Wschodzie, „Przedświt” (1920), nr 3. Por. K. Grygajtis, op. cit., s. 117-125; Krajowość - tradycje zgody narodów w dobie nacjonalizmów, red. J. Jurkiewicz, Poznań 1999, passim; M. Mackiewicz, Koncepcje społeczno-polityczne grupy wileńskich krajowców-demokratów w latach 1906-1911, „Folia Iuridica Universitatis Wratislaviensis” (2013), nr 1, s. 101-113.

9 R. Wapiński, Świadomość polityczna..., s. 215.

${ }^{10}$ K. Grünberg, op. cit., s. 258. Szerzej o tych wizjach zob. ibidem, s. 258-290.

11 J. Lewandowski, Federalizm..., s. 81-86; A. Deruga, Polityka wschodnia..., s. 19.

12 Sprawa Petlury, „Nowa Reforma” (21 XI 1920), nr 377.

13 A. Czarniakiewicz, Kształtowanie się ośrodka polonofilskiego w białoruskim ruchu narodowym (listopad 1918 - grudzień 1919), „Białoruskie Zeszyty Historyczne” (2008), z. 29, s. 26-28; J. Faryś, op. cit., s. 29. 
W powołanym 18 listopada 1918 r. rządzie Jędrzeja Moraczewskiego program federacyjny popierali piłsudczycy: minister spraw zagranicznych Leon Wasilewski, jego zastępca Tytus Filipowicz, kierownik Sekcji Wschodniej Witold Jodko-Narkiewicz i stojący na czele Wydziału ds. Rosji, Finlandii, Łotwy, Ukrainy, Kaukazu i Persji Roman Knoll. Ten ostatni uważał federację Polski, Litwy i Ukrainy za wariant optymistyczny. Sondował w tej kwestii nawet metropolitę greckokatolickiego Lwowa Andrieja Szeptyckiego. W instrukcji dla przedstawiciela polskiego w Kijowie zwracał uwagę: „Idea federacji nie powinna być oficjalnie ujawniana przez nasze czynniki miarodajne, może ona natomiast być wysuwana w prasie"14. Analiza działań czynników rządowych w następnych tygodniach wskazuje, że to założenie wzięto sobie do serca. Wysłannicy Piłsudskiego na konferencję pokojową, jak Kazimierz Dłuski czy Wasilewski, propagowali rozwiązania federacyjne w tamtejszej prasie. Rozmawiano o tym w Paryżu m.in. z Litwinami, w zamian oferując uznanie Litwy w granicach historycznych ${ }^{15}$. Także następny premier, Ignacy Jan Paderewski był zwolennikiem rozwiązań federacyjnych i generalnie aprobował wschodnią politykę Piłsudskiego ${ }^{16}$.

Idee federacyjne spotkały się ze zdecydowanym sprzeciwem endecji i pomniejszych ugrupowań prawicowych, promujących wizję unitarnego państwa narodowego. Odnośnie do ziem wschodnich dawnej Rzeczypospolitej forsowano koncepcję inkorporacyjną zakładającą ich podział pomiędzy Polskę i Rosję. Opowiadała się za tym większość wybranego w styczniu 1919 r. Sejmu Ustawodawczego ${ }^{17}$. Kluczowa dyskusja na temat federacji odbyła się 2 marca 1919 r. na posiedzeniu Komitetu Narodowego Polskiego w Paryżu. Obie strony sporu przedstawiły swoje argumenty za i przeciw tej idei. Zachęcał do niej wchodzący w skład Komitetu z ramienia Naczelnika Państwa Antoni Sujkowski. Powołując się na wielokrotne rozmowy z Piłsudskim, przekonywał, że rozwiązanie federacyjne, którego zwolennikiem jest ten ostatni, daje szanse na stworzenie silnego państwa, chroni przed Rosją, a także zarzutami imperializmu ze strony Zachodu, a jednocześnie broni przed przewaga żywiołu niepolskiego we wspólnym państwie. Inny delegat Piłsudskiego, Medard Downarowicz podnosił, że nawet przy formalnej odrębności części litewskiej i tak byłaby ona pod przemożnym wpływem polskiej kultury. W odpowiedzi przewodniczący Komitetu Roman Dmowski zarzucał, że Litwini ani Ukraińcy nie mają

${ }^{14}$ Cyt. za: A. Deruga, Polityka wschodnia..., s. 25; por. J. Pisuliński, Nie tylko Petlura. Kwestia ukraińska w polskiej polityce zagranicznej w latach 1918-1923, Wrocław 2004, s. 103-105.

15 A. Deruga, Polityka wschodnia..., s. 72-82; S. Mikulicz, Prometeizm w polityce II Rzeczypospolitej, Warszawa 1971, s. 32-34; A. Nowak, op. cit., s. 196-197, 250-253; J. Pisuliński, Nie tylko..., s. 100-105. Rozmowy te nie przyniosły powodzenia, gdyż Litwini optowali za swoim państwem narodowym.

16 W 1917 r. przedstawił prezydentowi USA Woodrow Wilsonowi pomysł Stanów Zjednoczonych Polski, składających się z królestw: Polski, Litwy, Polesia, Halicza i Podola oraz Wołynia. Szersza analiza tego projektu zob. M. Kornat, op. cit., s. 375-381.

17 Szerzej zob. np.: R. Wapiński, Świadomość polityczna..., s. 198-204; J. Faryś, op. cit., s. 31-35. 
zdolności państwowotwórczych i że federacja to słabość, nie siła, wymaga zdolności do kompromisu, której nie mają Litwini i inne narody kresowe. Do państwa jednolitego, niepodzielnego, z jednym sejmem i rządem, włączyć należy tylko takie obszary, które zapewnią Polakom bezwzględną przewagę narodową. W głosowaniu za federacją opowiedziało się tylko trzech jego członków, przeciwko - 11 (przy 1 głosie wstrzymującym się) $)^{18}$.

Za początek realizacji rozwiązań federacyjnych przez Naczelnika Państwa uważa się powszechnie jego odezwę „Do mieszkańców byłego Wielkiego Księstwa Litewskiego” z kwietnia 1919 r. ${ }^{19}$ Jak trafnie zauważał już Piotr Łossowski: „wiele obiecywała, pozostawiając otwarte drzwi do różnorodnych rozwiązań", także federacji ${ }^{20}$. Warto dodać, że komisarzem generalnym ziem wschodnich uczynił Piłsudski jej propagatora, Jerzego Osmołowskiego ${ }^{21}$. Do dzisiaj kwestia, czy Piłsudski był rzeczywiście zwolennikiem koncepcji federacyjnych, dzieli badaczy. Część z nich zarzuca mu, że posługiwał się tą ideą czysto koniunkturalnie ${ }^{22}$. Przytaczają na dowód fragment jego listu do Wasilewskiego: „Znasz moje pod tym względem poglądy, polegające na tym, że nie chcę być ani federalistą ani imperialistą, dopóki nie mam możliwości mówienia o tym $\mathrm{z}$ jaką taką powagą - no i z rewolwerem w kieszeni. Wobec tego, że na bożym świecie zaczyna zdaje się zwyciężać gadanina o braterstwie ludzi i narodów i doktrynki amerykańskie, przychylam się z miłą chęcią na stronę federalistów"23. W sierpniu 1923 r. w wykładzie wygłoszonym w Wilnie mówił: „Ja twierdziłem że iść tą drogą wydaje mi się niemożliwe. Zasad federacji nie da się zastosować na tych ziemiach. Przychodzimy wszak z bronią, co jest sprzeczne $\mathrm{z}$ zasadami federacji. Zresztą nie widziałem tutaj tych, który by do tej federacji chcieli przystąpić. Przysłowie mówi: «że w tym cały jest ambaras, żeby dwoje chciało naraz», a mianowicie - nie chciałem, aby Polskę federować $\mathrm{z}$ tą stroną, która się od nas, jako federant, odwróciła"24. Przywołuje się jednak też inne jego stwierdzenie: „Ja przegrałem swoje życie. Nie udało mi się powołać do życia dużego związku federacyjnego, z którym świat musiałby się liczyć" 25 .

Koncepcje federacyjne bardziej jednak funkcjonowały w publicystyce niż w bieżącej polityce. Temat unii czy federacji pojawiał się na łamach prasy od początku 1919 r. Wraz z posuwaniem się Wojska Polskiego coraz bardziej na wschód wiosną

18 Protokół posiedzenia KNP, 2 III 1919, w: Sprawy polskie na konferencji pokojowej w Paryżu w 1919. Dokumenty i materiały, red. R. Bierzanek, J. Kukułka, t. 1, Warszawa 1965, s. 79-103.

19 Zob. np.: B. Miedziński, op. cit., s. 6.

20 P. Łossowski, Stosunki polsko-litewskie w latach 1918-1920, Warszawa 1966, s. 100.

21 A. Nowak, op. cit., s. 279.

22 Szerzej zob. J. Pisuliński, Czy Piłsudski..., s. 111-126.

${ }^{23}$ List do Leona Wasilewskiego, 8 IV 1919, w: J. Piłsudski, Pisma zbiorowe, t. 5, Warszawa 1937, s. 73.

${ }^{24}$ Sprawa wileńska: wykład pierwszy, 23 VIII 1919, w: J. Piłsudski, op. cit., t. 6, s. 121-125. Por. A. Piłsudska, Wspomnienia, Londyn 1960, s. 314.

25 T. Katelbach, Rola Piłsudskiego w sprawie polsko-litewskiej, „Niepodległość” 1 (po wznowieniu) (1948), cyt. za: S. Mikulicz, op. cit., s. 48. 
i latem tego roku obserwujemy najintensywniejsze propagowanie idei federalistycznych i krystalizowanie się pomysłów. Formułowano je głównie na łamach takich czasopism, jak „Gazeta Polska”, „Rząd i Wojsko”, „Kurier Polski” (zbliżony do polskiego Ministerstwa Spraw Zagranicznych), „Gazeta Ludowa”, „Wyzwolenie”, wydawany przez Towarzystwo Straży Kresowej „Wschód Polski”, socjalistyczne periodyki „Naprzód”, „Przedświt” czy „Robotnik”. Głównymi propagatorami takiego rozwiązania byli Skwarczyński, Hołówko, Mieczysław Niedziałkowski, Wincenty Lutosławski i Adam Tarnowski ${ }^{26}$. Już w drugim numerze „Rządu i Wojska” z 12 stycznia anonimowy autor artykułu Sprawa Litwy proponował unię obu państw. Później rozwijano ją w wizję federacji narodów Litwy historycznej w ich granicach etnograficznych: polskiego, litewskiego i białoruskiego. Tak ukształtowane państwo przyciągałoby sąsiednie narody Łotyszy i Estończyków, a nawet Prusy Wschodnie. Warto zwrócić uwagę, że w artykule nie wspomniano o relacjach takiego państwa $\mathrm{z}$ Rzecząpospolitą ${ }^{27}$.

Sygnał do intensyfikacji dyskusji dał artykuł wstępny w „Gazecie Polskiej” z 16 marca, w którym przedstawiano program federacji z Białorusią i Litwą, w dalszej kolejności z państwami bałtyckimi. Na łamach wspomnianych wyżej gazet, a także w osobnych broszurach rozwiązanie federacyjne funkcjonowało najczęściej w dwóch wariantach: częstszym trójczłonowym (związku Polski, Litwy i Białorusi) i z dodaniem Ukrainy. Pojawiały się też sporadycznie koncepcje obejmujące większą liczbę części składowych, biorące pod uwagę także pozostałe państwa bałtyckie (m.in. Hołówki czy Skwarczyńskiego). Często również pisano o konieczności szerszego związku państw sąsiadujących z Rosją, od Finlandii po Ukrainę, by wspólnie przeciwstawić się Rosji i stworzyć mocarstwo (m.in. Jan Starzewski). Na posiedzeniu sejmowej Komisji Spraw Zagranicznych w październiku 1919 r. Ignacy Daszyński formułował to w ten sposób, że Polska winna być ośrodkiem dla narodów ujarzmionych przez Rosję, od Finlandii po Ukrainę. Niedziałkowski w ślad za Michałem Romerem pisał zaś o analogicznym Bloku Narodów ${ }^{28}$.

26 J. Lewandowski, Federalizm..., s. 226.

27 Sprawa Litwy, „Rząd i Wojsko” (12 I 1919), nr 2 (33); zob. też: Sprawa Litwy i Białorusi, „Rząd i Wojsko” (2 III 1919), nr 9 (40); T. Hołówko, Z kim walczyć?, „Robotnik” (5 II 1919), nr 57.

28 Zob. np.: J.D., Ukraina zjednoczona, „Kurier Polski” (1919), nr 28; A.Z., Nowy program wschodni, „Kurier Polski” (17 VIII 1919), nr 212; artykuł wstępny „Gazety Polskiej” (16 III 1919); T. Hołówko, Perspektywy historyczne II, „Robotnik” (24 IV 1919), nr 166; idem, Zadania Polaków na Litwie, "Robotnik” (6 V 1919), nr 178; idem, Stosunek państwa polskiego do jego sąsiadów, „Przedświt” (1919), nr 5/6; Linie wytyczne polityki narodowej, „Rząd i Wojsko” (1919), nr 6 (37); Niepodległa Ukraina, „Rząd i Wojsko” (1919), nr 7 (38); Do polskich partii ludowych. W sprawie polityki zagranicznej ludu polskiego, „Rząd i Wojsko” (30 III 1919), nr 13 (44); Wolna z Rosją czy wojna z Ukraina, „Rząd i Wojsko” (20 IV 1919), nr 16 (47); T. Hołówko, Równi z równymi, wolni z wolnymi, „Rząd i Wojsko” (20 IV 1919), nr 18 (49); J.S. [Jan Starzewski], Na drodze do rozwiązania sprawy Litwy historycznej. Etapy polskiej myśli politycznej, Kraków 1920; W. Lutosławski, Bolszewizm i Polska, Poznań 1920; A. Skwarczyński, Cele Polski na wschodzie, Warszawa 1920. Szerzej zob. A. Deruga, Polityka wschodnia..., s. 81-82; M. Boruta, Wolni $z$ wolnymi, równi $z$ równymi. Polska i Polacy o niepodległości wschodnich sąsiadów 
Tak zbudowany związek, mający więcej mieszkańców niż weimarskie Niemcy, byłby niewątpliwie potencjalnie silnym tworem.

W dostępnych źródłach trudno znaleźć powody, dla których w sporej części prezentowanych wyżej koncepcji nie uwzględniano Ukrainy, skoro z uwagi na zaludnienie i powierzchnię kraju znacznie wzmacniałaby przyszłe państwo. Zdaniem Józefa Lewandowskiego obawiano się, że ruch narodowy w rosyjskiej części Ukrainy z czasem upodobni się do antypolskiego nacjonalizmu prezentowanego przez Ukraińców ze wschodniej Galicji ${ }^{29}$. Nie da się jednak też wykluczyć, że kryła się za tym obawa, że w takim tworze Polacy byliby mniejszością, podczas gdy w państwie trialistycznym Białorusinów czy Litwinów łatwo przyszłoby zdominować (zasymilować?), a przynajmniej utrzymać pod kontrolą.

Spór federalistów z przeciwnikami tego rozwiązania w mniejszym stopniu odbywał się również na forum sejmowym. Już jednak na jednym z pierwszym posiedzeń Sejmu Ustawodawczego 22 lutego propozycję federacji podnosili Błażej Stolarski z PSL „Wyzwolenie” i Daszyński ${ }^{30} .27$ marca do idei tej wrócił poseł Kamieniecki. Feliks Perl mówił wówczas o stworzeniu „nowoczesnej federacji” na drodze porozumienia sił demokratycznych Polski, Litwy, Białorusi i Ukrainy, zatwierdzonej przez konstytuantę wybraną w pięcioprzymiotnikowych wyborach. Zwracał jednak uwagę na to, że federacja jest formą ustrojową trudną do przeprowadzenia, gdyż wymaga dobrowolnej zgody obu stron, nie może zostać narzucona siłą. Poza tym istniejące na świecie tego rodzaju państwa są jednonarodowe ${ }^{31}$. Kilka dni później Niedziałkowski wskazywał na federację jako jedyną podstawę budowania silnego, a zarazem wolnego i szczęśliwego państwa poprzez porozumienie z wszystkimi czynnikami, które chcą schować się pod jej skrzydła: „My sądzimy, że warunkiem nawiązania pomiędzy Polską a Litwą i Białorusią istotnie prawdziwego związku, warunkiem istotnym odbudowania dawnej unii w tej czy innej formie, jest to, ażeby Polska była siła przyciągającą, była tym magnesem, który ściąga do siebie wszystkie sąsiednie ludy"32. Niewątpliwie przy całym sztafażu „nowoczesnej” formuły pobrzmiewała w tym tęsknota za wspólną przeszłością ${ }^{33}$.

Rzeczypospolitej, Kraków 2002, s. 164-166; A. Nowak, op. cit., s. 355; Ł. Zweiffel, Państwa bałtyckie..., s. 291-293; J. Lewandowski, Federalizm..., s. 84; P. Okulewicz, op. cit., s. 42-51.

${ }^{29} \mathrm{~J}$. Lewandowski, Imperializm słabości. Kształtowanie się koncepcji polityki wschodniej piłsudczyków 1921-1926, Warszawa 1967, s. 52; idem, Kwestia ukraińska w II Rzeczypospolitej, „Aneks” (1982), nr 28, s. 103.

${ }^{30}$ J. Lewandowski, Federalizm..., s. 104-106; A. Nowak, op. cit., s. 354-358; J. Pisuliński, Nie tylko..., s. 133-134.

31 Sprawozdania Stenograficzne Sejmu Ustawodawczego (dalej: SSSU), posiedzenie 19, 27 III 1919, 1. 1126-1131, 1147; M. Śliwa, Kwestia narodowościowa w programach i publicystyce socjalistów polskich w okresie Drugiej Rzeczypospolitej, „Dzieje Najnowsze” (1983), nr 1-2, s. 108.

32 SSSU, pos. 24, ł. 40. Dalej zauważał, że Wielkie Księstwo Litewskie jest wspólną własnością ludu polskiego, litewskiego i białoruskiego.

33 A. Deruga, Polityka wschodnia..., s. 30; E. Koko, W nadziei na zgodę. Polski ruch socjalistyczny wobec kwestii narodowościowej w Polsce (1918-1939), Gdańsk 1995, s. 146. Niedziałkowski pisał: 
Charakterystyczne jednak, że pomysły federacyjne nie pojawiły się praktycznie w ogóle w dyskusjach o ustroju państwa ${ }^{34}$.

Najwięcej zwolenników rozwiązań federacyjnych było wśród socjalistów i bliskich im intelektualistów. Socjaliści od początku uznawali za paradygmat prawo narodów do samostanowienia o sobie i dostrzegali aspiracje narodowe Litwinów, Białorusinów i Ukraińców. Projekt federacyjny pozwalał pogodzić te dążenia z objęciem przez takie państwo wszystkich skupisk polskich na wschodzie ${ }^{35}$. Głosili ją najwybitniejsi teoretycy ruchu począwszy od Bolesława Limanowskiego, poprzez Kazimierza Kelles-Krauza, po Wasilewskiego. Idea federacji była wpisana w program PPS od samego jej początku. Do idei tej odwoływali się liderzy partii: Daszyński, Niedziałkowski, Herman Lieberman czy Bronisław Ziemięcki. W marcu 1917 r. w uchwałach XIII Zjazdu wyrażano nadzieje na zjednoczenie Białorusi, Litwy i Polski na zasadzie dobrowolnego związku państwowego ${ }^{36}$. Liczono, że te narody same będą chciały wejść w związek z Polską dla osłony przed Rosją, bo polityka rusyfikacyjna tej ostatniej groziła zagładą ich odrębności narodowej, którą natomiast mogliby spokojnie kultywować w federacji z Polakami ${ }^{37}$. Ponadto skłaniać będzie ich do tego niemożność ścisłego rozgraniczenia etnograficznego, chociażby przez fakt, że w ich granicach leżały silne polskie centra Lwów i Wilno. Socjaliści zastrzegali się, że federację można budować tylko drogą pokojową. Według Barbary Stoczewskiej ich wizje ewoluowały, początkowo związek narodów kresowych z Polską miał funkcjonować pod wyraźnym protektoratem tej ostatniej. Pierwszy krok widzieli w odrodzeniu unii polsko-litewskiej na nowych demokratycznych zasadach, przy czym chodziło o tzw. Litwę historyczną. W zamian za przystąpienie do unii socjaliści jako jedyni gotowi byli oddać Litwinom północną (litewskojęzyczną) część Suwalszczyzny i nawet Wilno (jednakże już nie Lwów czy Chełmszczyznę Ukraińcom) ${ }^{38}$. Jedynie nieliczni, jak

„Odrodzona przez wspólną walkę i wspólną ofiarę, odnowiona przez wolę ludów - nie władców Unia Lubelska trwa i trwać nie przestanie”, cyt. za: M. Śliwa, Federalizm..., s. 141.

${ }^{34}$ Wyjątkiem był napisany przez profesora Józefa Buzka projekt konstytucji (tzw. amerykański), zgłoszony w maju 1919 r. przez kilkunastu posłów ludowców i z niewielkich ugrupowań, jak Polskiego Zjednoczenia Ludowego czy Klubu Pracy Konstytucyjnej, który przewidywał podział na aż 70 ziem. W. Jakubowski, K. Jajecznik, Polska debata ustrojowa w latach 1917-1921, Warszawa 2010, s. 32-33, 119-125.

35 R. Wapiński, Polska myśl polityczna XIX i XX wieku, Gdańsk 1997, s. 167.

36 J. Lewandowski, Federalizm..., s. 81; R. Wapiński, Polska myśl..., s. 166-168; S. Michałowski, Mniejszości narodowe w myśli politycznej socjalistów polskich (1892-1939), w: Między rzeczywistościa polityczna a światem iluzji. Rozwiązanie problemu mniejszości narodowych w polskiej myśli politycznej XX wieku, red. J. Jachymek, W. Paruch, Lublin 2002, s. 161-165; B. Stoczewska, Litwa, Białoruś, Ukraina w myśli politycznej Leona Wasilewskiego, Warszawa 2009; eadem, Ukraina i Ukraińcy w polskiej myśli politycznej od końca XIX wieku do wybuchu II wojny światowej, Kraków 2013, s. 115-148; A. Wojtaszak, op. cit., s. 247-264.

37 M. Śliwa, Federalizm..., s. 141.

${ }^{38}$ Idem, Kwestia narodowościowa..., s. 109; R. Wapiński, Świadomość polityczna..., s. 214; E. Koko, op. cit., s. 27, 146; Ł. Zweiffel, „O program”..., s. 232-234; B. Stoczewska, Ukraina..., s. 264-266. 
Hołówko, Kazimierz Zakrzewski czy Filipowicz, przewidywali rozciągnięcie federacji na południe i objęcie nią Ukrainy ${ }^{39}$.

Ideę federacyjną socjaliści wiązali z tak ważnymi dla nich reformami społecznymi. Przemiany te miały zdjąć z Polaków odium narodu "panów i dziedziców” w oczach Litwinów, Białorusinów czy Ukraińców, przekonując do federacji lub unii ${ }^{40}$. Chodziło też o przeciwdziałanie propagandzie bolszewickiej i głoszonym przez nią nośnym hasłom społecznym. $Z$ tego punktu krytykowano inkorporację jako popieraną przez właścicieli ziemskich, tym samym dająca paliwo tej propagandzie. Hołówko pisał, że aneksja leży tylko w interesie miejscowych polskich obszarników i burżuazji, prowadziłaby do stałej i systematycznej walki z tymi narodami ${ }^{41}$. Publicyści socjalistyczni zwracali również uwagę na korzyści gospodarcze dla narodów partycypujących w federacji w postaci dostępu do Bałtyku i Morza Czarnego. Podnosili też, że w trakcie wspólnej przeszłości powstały związki ekonomiczne pozwalające stworzyć z zachodnich części dawnego Imperium Rosyjskiego jeden kompleks gospodarczy ${ }^{42}$.

W obliczu niepowodzenia pomysłów federacyjnych, przede wszystkim odrzucania ich przez miejscową ludność, Hołówko wyrażał nadzieję, że zmieni ona zdanie pod wpływem demokratyzacji w samej Polsce i zmiany postaw miejscowych polskich środowisk ${ }^{43}$. Natomiast Niedziałkowski w ślad za Kamienieckim proponował jako alternatywę koncepcję kantonalno-federacyjną, a więc większej liczby składowych federacji, bardziej homogenicznych narodowościowo i religijnie. Postulował więc wyodrębnienie Litwy etnograficznej (Kowieńszczyzna), strefy katolickiej polsko-białoruskiej (północna część Grodzieńszczyzny, część dawnej guberni wileńskiej z Wilnem i Nowogródczyzna) oraz okręgu białoruskiego - prawosławnego z Mińskiem. W pierwszej strefie przeważaliby Litwini, w drugiej - Polacy, w trzeciej - Białorusini. Granice wyznaczono by w drodze plebiscytu. Rozwiązanie takie przyjęłaby i zatwierdziła wyłoniona wśród miejscowych konstytuanta albo dwie, osobna dla terenów polsko-białoruskich, osobna dla białorusko-prawosławnych. W każdym z „kantonów” obowiązywałyby dwa języki urzędowe. Tworzyłyby one razem Stany Zjednoczone Litwy i Białorusi, zorganizowane na wzór Związku Szwajcarskiego. Posiadałyby wspólny sejm krajowy. Niedziałkowski przewidywał zawarcie przez taki twór unii z Rzecząpospolitą ${ }^{44}$. Podobną koncepcję głosił Perl. Postulował powołanie czterech kantonów ze stolicami w Kownie, Wilnie, Mińsku

39 E. Koko, op. cit., s. 18; M. Boruta, op. cit., s. 164-165. Zob. np.: Krzewski [K. Zakrzewski], Zasady federacji w polskiej polityce kresowej, Kraków 1920.

40 Własne sity, „Rząd i Wojsko” (2 III 1919), nr 9 (40). Por. A. Deruga, Polityka wschodnia..., s. 29.

${ }^{41}$ T. Hołówko, Stosunek państwa polskiego do jego sąsiadów, „Przedświt” (1919), nr 1-2.

42 J. Lewandowski, Federalizm..., s. 83-85; M. Śliwa, Kwestia narodowościowa..., s. 109.

43 A. Deruga, Polityka wschodnia..., s. 29.

${ }^{44}$ M. Niedziałkowski, O polski program na Wschodzie... W odniesieniu do kresów południowo-wschodnich Niedziałkowski postulował podobne rozwiązanie (już bez szczegółów), o ile Ukraińcy nie byliby zdolni do stworzenia organizmu państwowego. 
i Kłajpedzie. Innym z pomysłów było wspomniana idea Hołówki stworzenia bloku państw od Finlandii po Ukrainę, który dawał możliwość przeciwstawienia się Rosji, jak i Niemcom. Nazwał go „Stanami Zjednoczonymi Europy”. Niedziałkowski szedł dalej - proponował objęcie „blokiem ludów” nie tylko Europy Wschodniej, ale i Środkowej z krajami Małej Ententy ${ }^{45}$.

Tenże przedkładał państwo federacyjne nad proste inkorporowanie kresów, gdyż wówczas:

Mielibyśmy państwo jednolite, a więc $\mathrm{w}$ dostatecznej mierze centralistyczne, przepełnione tendencjami odśrodkowemi, z Sejmem, w którym dwie piąte posłów mogłoby uczestniczyć stale w obstrukcjach na tle narodowościowym, państwo, rzucone lekkomyślnie w wir nieustannych walk wewnętrznych, zagrożone rozkładem, państwo w stylu dawnego Imperium Rosyjskiego lub Austrii przed 1866 r. [...] sytuacja podobna prowadziłaby z siłą nieubłaganą do rządów militarystyczno-policyjnych, do metody prześladowań, ucisku, sztucznego wynaradawiania, skutki ostateczne przewidzieć łatwo ${ }^{46}$.

Wapiński słusznie dostrzegał, że federacyjne wizje socjalistów opierały się na dwóch założeniach: idealizacji wspólnej przeszłości w ramach I Rzeczypospolitej i przekonaniu, że wprowadzenie $\mathrm{w}$ życie idei socjalizmu automatycznie rozwiąże konflikty narodowościowe ${ }^{47}$.

Warto w tym miejscu jednak zauważyć, że daleko nie wszyscy socjaliści popierali rozwiązania federacyjne. Wielu $\mathrm{z}$ nich sceptycznie zapatrywało się na możliwość ich wdrożenia. Kazimierz Domosławski w polemice z Hołówką na łamach „Przedświtu” wątpił w zdolności państwowotwórcze Białorusinów czy Ukraińców. Zmuszało to do rozciągnięcia nad nimi protektoratu, szkodliwego zarówno dla nich, jak i dla samej Polski. Podobnie krytycznie o „wychowawczej” misji Polski wobec tych narodów wypowiadał się Adam Próchnik. Generalnie zarzuty w stosunku do federacjonizmu padały najczęściej od najbardziej radykalnych członków partii, jak Tadeusz Żarski czy Jerzy Czeszejko-Sochacki, którzy dostrzegali w nim zawoalowany imperializm klas posiadających ${ }^{48}$.

Wśród ruchu ludowego rozwiązania federacyjne od początku popierało PSL „Wyzwolenie”, w tym czołowi jego liderzy: Tomasz Nocznicki, Maciej Rataj, Błażej

45 T. Hołówko, Perspektywy historyczne II...; idem, Zadania Polaków na Litwie...; A. Deruga, O federalizmie..., s. 319; M. Śliwa, Kwestia narodowościowa..., s. 111; idem, Federalizm..., s. 142-143; I. Werschler, $Z$ dziejów obozu belwederskiego. Tadeusz Hołówko życie i działalność, Warszawa 1984, s. 106-108; M. Boruta, op. cit., s. 145.

${ }^{46}$ M. Niedziałkowski, O polski program na Wschodzie..., s. 9.

47 R. Wapiński, Polska i małe ojczyzny Polaków. Z dziejów kształtowania się świadomości narodowej XIX i XX wieku po wybuch II wojny światowej, Wrocław-Warszawa-Kraków 1994, s. 222-224.

${ }^{48} \mathrm{~K}$. Domosławski, Złudzenia i rzeczywistość (W odpowiedzi tow. Hołówce na jego artykuł „Stosunek państwa polskiego do jego sasiadów”), „Przedświt” (1919), nr 7-8. Szerzej zob. M. Śliwa, Kwestia narodowościowa..., s. 112-114; B. Stoczewska, Ukraina..., s. 266-268; R. Wapiński, Polska i małe ojczyzny..., s. 223-224. 
Stolarski czy Stanisław Thugutt (specjalizujący się w zagadnieniach narodowościowych), ale też mniej znani, jak wspomniany Pohoski. Podobnie jak socjaliści wiązali $\mathrm{z}$ tą ideą wizję reform społecznych przeprowadzonych w imię interesów tamtejszego chłopstwa. W uchwałach walnego zjazdu z lutego $1920 \mathrm{r}$. domagano się całkowitej wolności dla ludu ziem wschodnich do decydowania o swoim losie. Liczono na to, że wybierze on związek z Polską przy poszanowaniu praw i odrębności kulturowej ${ }^{49}$.

Zwolenników rozwiązań federacyjnych znajdziemy również w kręgach lewicowo i liberalnie nastawionej inteligencji, m.in. głosili je wybitni intelektualiści: Olgierd Górka, Oskar Halecki, Handelsman, Ludwik Kolankowski, Stanisław Kutrzeba, Wacław Lednicki, Edward Maliszewski, Sujkowski, Włodzimierz Wakar, prezydent Wilna Witold Abramowicz, Ludwik Chomiński, Aleksander Lednicki, Sieroszewski, Stanisław Stempowski czy Marian Świechowski ${ }^{50}$. Filozof Lutosławski wysuwał nawet pod koniec 1919 r. ideę unii ludów środkowej Europy, od Finlandii po Królestwo SHS ${ }^{51}$.

Politykę wschodnią Piłsudskiego popierała też Narodowa Partia Robotnicza. Idee federacyjne sporadycznie pojawiały się w innych ugrupowaniach. Wspomniany Kamieniecki z Narodowego Zjednoczenia Ludowego już pod koniec 1918 r. w serii wydawniczej pod wspólnym tytułem „Wolni z wolnymi, równi z równymi” opublikował broszurę Państwo litewskie. Postulował w niej odbudowę Litwy w granicach historycznych, powiązanej z Rzecząpospolitą, złożonej z autonomicznych krain: Żmudzi, Litwy, Podlasia, Białorusi i Polesia bądź też z trzech kantonów: kowieńskiego, wileńskiego i mińskiego. Miały one posiadać sejmy krajowe z kompetencjami podobnymi do sejmu galicyjskiego i centralnym rządem związkowym w Wilnie. Byłoby to więc rozwiązanie kantonalne, podobne do Związku Szwajcarskiego. Kamieniecki nie precyzował związków takiego państwa z Polską, choć je przewidywał. Podobnie czynił w przygotowanym wspólnie z profesorami Kutrzebą i Maliszewskim „Planie prac nad polską granicą wschodnią”, złożonym w Biurze Prac Kongresowych przy delegacji na konferencję pokojową w Paryżu ${ }^{52}$.

Koncepcje federacyjne formułowano również w niektórych środowiskach konserwatywnych, głównie, co zrozumiałe, wywodzących się z Kresów Wschodnich. Prezentowano je w środowisku konserwatystów wileńskich, w kręgu „Głosu Kresowego" wydawanego przez Szymona Meysztowicza, głosił je też Władysław Wielhorski. W tej wizji w skład federacji wchodziłyby tylko tereny litewskie

49 M. Rataj, Pamiętniki (1918-1927), Warszawa 1965, s. 48, 76; J. Lewandowski, Federalizm..., s. 81-88; J. Jachymek, Rozwiązanie problemu mniejszości narodowych. Ruch ludowy (1918-1939), w: Między rzeczywistościa polityczną..., s. 147; B. Stoczewska, Ukraina..., s. 314.

${ }^{50}$ J. Lewandowski, Federalizm..., s. 88-89; K. Grygajtis, op. cit., s. 232-240; M. Boruta, op. cit., s. 159-160; M. Kornat, op. cit., s. 386-404. Świechowski był autorem broszury O program w stosunku do ziem litewsko-białoruskich, Wilno 1920.

${ }^{51}$ M. Boruta, op. cit., s. 157-159; K. Grygajtis, op. cit., s. 249-252.

52 W. Kamieniecki, Państwo litewskie, Warszawa 1918; zob. J. Lewandowski, Federalizm..., s. 89-96; A. Deruga, O federalizmie..., s. 319; J. Faryś, op. cit., s. 66; Г. Корольов, op. cit., c. 231-234. 
i białoruskie. Natomiast Ukrainę traktowali jako fikcję stworzoną przez Niemców. Konserwatyści krakowscy, w przeciwieństwie np. do środowisk wielkopolskich, wileńskich czy lwowskich, także popierali rozwiązania federacyjne, m.in. na łamach „Czasu”. Jeszcze w okresie wyprawy kijowskiej w 1920 r. Stanisław Estreicher opowiadał się za Ukrainą sfederowaną z Polską. Wybitny historyk Halecki widział w federacji obok Polski i Wielkiego Księstwa Litewskiego Ukrainę. Przewidywał, że do tak potężnego państwa dołączyłyby w przyszłości Łotwa i Estonia, a także Gdańsk z Prusami Wschodnimi ${ }^{53}$. Wydaje się, że za projektami konserwatystów stała często nie tyle gotowość zaspokojenia aspiracji narodów kresowych, ile chęć utrzymania dominacji Polaków.

Dla większości Polaków z ziem wschodnich lansowany przez endecję program bezpośredniej inkorporacji do Rzeczypospolitej zamieszkałych przez nich terenów był dużo bardziej zrozumiały i przez nich popierany ${ }^{54}$. Koncepcje federalistyczne miały pewne poparcie na pograniczu litewsko-białorusko-polskim, gdzie mniejsze było natężenie konfliktów narodowościowych, niż na południu ogarniętym wojną o Lwów. Popierali je miejscowi socjaliści (z Polskiej Partii Socjaldemokratycznej Litwy i Białorusi), powstałe na tych terenach PSL „Odrodzenie”, demokraci wileńscy i część ziemiaństwa (ze wspomnianego kręgu krajowców), m.in. na łamach takich czasopism, jak „Gazeta Krajowa”, „Nasz Kraj” czy „Przegląd Wileński”. Szczególną popularnością cieszyły się rozwiązania kantonalne. Wśród ich zwolenników byli Zygmunt Jundziłł, Bronisław Krzyżanowski, Świechowski, Tadeusz Wróblewski. Wiązało się to z dyskusją wokół propozycji Paula Hymansa, który z ramienia Ligi Narodów mediował w polsko-litewskim sporze o Wilno, lecz w przeciwieństwie do niego odrzucano rozwiązania konfederacyjne na rzecz ściślejszej federacji. Jednakże na ogół idea federacji przegrywała u miejscowych Polaków z pragnieniem bezpośredniego włączenia do Rzeczypospolitej ${ }^{55}$.

Część badaczy skłania się do tezy, że Naczelnik Państwa wraz z resztą obozu belwederskiego w zasadzie porzucił idee federacyjne już jesienią 1919 r., po niepowodzeniu prób pozyskania doń Litwinów ${ }^{56}$. W publicystyce federację zastępował

53 E. Czapiewski, Koncepcje polityki zagranicznej konserwatystów polskich w latach 1918-1926, Wrocław 1988, s. 20-61; J. Faryś, op. cit., s. 64-66; J. Jurkiewicz, Rozwój polskiej myśli politycznej na Litwie i Białorusi w latach 1905-1922, Poznań 1983, s. 185-199; J. Bardach, Krajowcy, federaliści, inkorporacjoniści, w: idem, O dawnej i niedawnej Litwie, Poznań 1988, s. 263; M. Kornat, op. cit., s. 386-391. Zob. np.: W. Wielhorski, Państwowość Litwy etnograficznej wobec zagadnień trwałego pokoju w Europie, Warszawa 1919.

${ }_{54}$ Zob. np.: J. Gierowska-Kałłaur, Straż Kresowa wobec kwestii białoruskiej. Deklaracje i praktyka, „Studia z Dziejów Rosji i Europy Środkowo-Wschodniej” 44 (2009), s. 24.

55 Por. R. Wapiński, Świadomość polityczna..., s. 213; K. Okulicz, Ostatni akt dramatu Józefa Piłsudskiego (1920-1922), „Zeszyty Historyczne” (1966), nr 9, s. 22; J. Jurkiewicz, op. cit., s. 197-201, 225-233; M. Kornat, op. cit., s. 395-404; Г. Корольов, ор. cit., c. 234, 299. Świechowski pisał o Unii dwóch dualizmów państwowych.

56 Zob. np.: J. Lewandowski, Imperializm słabości..., s. 44-51; P. Łossowski, Po tej i tamtej stronie Niemna. Stosunki polsko-litewskie 1883-1939, Warszawa 1985, s. 122-123; K. Grygajtis, op. cit., s. 138. 
ścisły sojusz polityczno-wojskowy nowo powstałych państw (od Finlandii po Ukrainę $^{57}$. W postanowieniach Rady Ministrów z 8 marca 1920 r., dotyczących warunków rozmów pokojowych z Rosją bolszewicką, zaniechano „utworzenia państwa białoruskiego sfederalizowanego z Polską" ${ }^{38}$. Nadal jednak idee federacyjne głoszono w publicystyce, m.in. w czasopiśmie „Rząd i Wojsko”. W komentarzu do wspomnianych propozycji pokojowych zastrzegano jednak, że ze względu na sprzeciw Rosji wobec podnoszenia praw do samostanowienia Białorusinów i Ukraińców należy się wstrzymać z głoszeniem programu federacyjnego ${ }^{59}$.

Wizje stworzenia federacji z krajami na wschód od Polski powróciły w kwietniu 1920 r., po zawarciu sojuszu Piłsudski-Petlura. Liberalno-demokratyczny „Naród” przywitał go komentarzem: „Polska stanęła wreszcie w obronie federalizmu, jako fundamentu przyszłych stosunków międzynarodowych i idei tej nadała kształt realny”60. Po rozpoczęciu wyprawy kijowskiej na łamach „Rządu i Wojska” Skwarczyński pisał: „Swą polityką zakłada ona [Polska - J.P.] podwaliny pod ustrój polityczny Europy Wschodniej, pod wolny związek ludów i czynem daje inicjatywę Ligi Narodów Europy Wschodniej"61. Dość nieoczekiwanie ideę poparło czasopismo PSL „Piast”. Pisano w nim, że zadaniem polskim na wschodzie jest utworzenie szeregu niezawisłych, sprzymierzonych z Polską lub wprost sfederowanych krajów, aby zabezpieczyć się przed Rosją ${ }^{62}$.

Klęska wyprawy kijowskiej w lecie 1920 r. spowodowała chwilowe zarzucenie projektów federacyjnych. Powrócono doń po Bitwie Warszawskiej. Między innymi na łamach „Robotnika” Niedziałkowski przypomniał koncepcję kantonalną ${ }^{63}$. W instrukcjach dla delegacji na rozmowy pokojowe $\mathrm{z}$ bolszewikami była mowa o niepodległym państwie ukraińskim, skonfederowanym z Polską i z innymi narodami w bloku krajów Europy Środkowo-Wschodniej. W delegacji znaleźli się dwaj wspomniani zwolennicy federacji: Kamieniecki i Wasilewski ${ }^{64}$. Już jednak jesienią 1920 r. nawet socjaliści odsuwali program federacyjny na bliżej nieokreśloną przyszłość, deklarując poparcie dla niepodległości wszystkich „limitrofów”

57 Zob. W. Balcerak, Koncepcje integracyjne w polskiej polityce zagranicznej 1918-1939, „Dzieje Najnowsze" (1970), nr 1, s. 35; P. Okulewicz, op. cit., s. 77-82, 108-110.

${ }^{58}$ Rok 1920. Wojna polsko-radziecka we wspomnieniach i innych dokumentach, wybór i oprac. J. Borkowski, Warszawa 1990, s. 114-116.

59 A. Skwarczyński, Cele wojny na wschodzie, „Rząd i Wojsko” (25 I 1920), nr 4 (82); J. Pohoski, Rezerwy sił w sprawie wschodniej, „Rząd i Wojsko” (8 II 1920), nr 6 (84); A. Skwarczyński, N.-Decja - a polskie warunki pokoju, „Rząd i Wojsko” (25 IV 1920), nr 17 (95).

${ }^{60}$ Cyt. za: B. Korzeniewski, Wyprawa kijowska w polskiej propagandzie prasowej, „Przegląd Humanistyczny" (2006), nr 1, s. 84.

${ }^{61}$ Cyt. za: ibidem, s. 86.

62 Ibidem, s. 84, 91.

${ }^{63}$ M. Niedziałkowski, Sprawa Wilna, „Robotnik” (2 IX 1920), nr 239; E. Koko, op. cit., s. 32.

${ }^{64}$ E. Charaszkiewicz, Przebudowa Wschodu Europy. Materiaty do polityki wschodniej Józefa Piłsudskiego w latach 1893-1921, „Niepodległość” 5 (po wznowieniu) (1955), s. 159-160; M.K. Dziewanowski, op. cit., s. 322; M. Boruta, op. cit., s. 181. 
od Finlandii po Ukrainę ${ }^{65}$. Tylko niestrudzony zwolennik idei Niedziałkowski podczas debaty sejmowej w listopadzie $1920 \mathrm{r}$. mówił o bloku ludów dawnej Rzeczypospolitej. Jednakże rok później pisał o federacji jako idei czasowo nieaktualnej, gdyż jej realizacja może wywołać konflikt militarny ${ }^{66}$.

Sprawa federacji powróciła na chwilę po powołaniu tzw. Litwy Środkowej w październiku 1920 r. Jako jeden z wariantów rozwiązania problemu wileńskiego wskazywała ją instrukcja ministra spraw zagranicznych Eustachego Sapiehy z 20 października 1920 r. ${ }^{67}$ Jako ośrodek budowy Stanów Zjednoczonych Litwy w federacji lub przymierzu z Polską widział ją Hołówko. Pisał o blizzej nieokreślonej terytorialnie „federacji wolnych, równouprawnionych narodów Wschodu Europy”. Pomysł polegał na zrzeczeniu się części suwerenności przez kraje członkowskie i powołaniu organizmu ze wspólnymi siłami zbrojnymi, polityką zagraniczną, gospodarczą (opartą na propagowanych przez socjalistów kooperatywach) i wymianą handlową ${ }^{68}$. Wileńscy federaliści postulowali federację trzech składowych: Litwy kowieńskiej, Litwy Środkowej i Białorusi. Konkurencyjna była propozycja dwóch kantonów: kowieńskiego i wileńskiego - po podziale terenów białoruskich w traktacie ryskim bardziej realna. W przyszłości, jeśli byłaby taka wola sejmów wileńskiego i warszawskiego, dopuszczano połączenie Polski i Litwy. Rozwiązanie to propagowało m.in. Biuro Prac Politycznych Stronnictw Lewicowych i Federalistycznych w Wilnie, powiązane z polskim Ministerstwem Spraw Zagranicznych. Przygotowany przez nie projekt zakładał oddzielne sejmy krajowe i władze wykonawcze, ale wspólny rząd w Wilnie oraz wspólną politykę zagraniczną, wojskową, finansową i komunikację. Pozostałe kwestie miały ustalać delegacje obu kantonów. Natomiast szereg krajowców odszedł wówczas od idei federacji, niemożliwej do zrealizowania z powodu sprzeciwu Litwinów, na rzecz odrębności państwowej Litwy (obejmującej zarówno część wileńską, jak i kowieńską $)^{69}$. Jednakże w wybranym w styczniu 1922 r. Sejmie Litwy Środkowej zwolennicy federacji zdobyli zaledwie 16 na 106 mandatów $^{70}$.

Tymczasem w czasie wspomnianych rokowań w Brukseli pomiędzy Polską a Litwą wiosną 1921 r. Hymans przedstawił projekt luźniejszego związku dwóch faktycznie niezależnych państw, połączonych jedynie wspólną radą ds. zagranicznych i szeregiem konwencji. Projekt nie zadowolił Warszawy. Strona polska opowiadała się za ściślejszymi związkami federacyjnymi. Minister spraw zagranicznych

${ }^{65}$ S. Mikulicz, op. cit., s. 73-74; B. Stoczewska, Ukraina..., s. 269.

${ }^{66}$ M. Śliwa, Federalizm..., s. 142; M. Boruta, op. cit., s. 178-180. Jeszcze w grudniu 1921 r. na łamach „Wschodu Polski” proponowana była koncepcja trialistyczna. B. Srocki, Przed rozstrzygnięciem sprawy wileńskiej, „Wschód Polski” (1921), nr 10-12.

67 K. Grygajtis, op. cit., s. 264; M. Kornat, op. cit., s. 405-406.

68 T. Hołówko, Nowe życie, „Przymierze” (30 I 1921), nr 4; S. Mikulicz, op. cit., s. 47; I. Werschler, op. cit., s. 108; M. Boruta, op. cit., s. 176.

69 J. Jurkiewicz, op. cit., s. 225-232; K. Grygajtis, op. cit., s. 318-328; M. Kornat, op. cit., s. 398-404.

70 J. Jurkiewicz, op. cit., s. 247. 
Sapieha zaproponował rozwiązania zbliżone do wysuwanych przez Biuro Prac Politycznych, wzorowane też na rozwiązaniach unii austro-węgierskiej z 1867 r.: wznowienie unii polsko-litewskiej ze wspólnym prezydentem, wybranym przez połączone litewskie sejmy kantonalne i polski parlament. Wspólne byłyby: polityka zagraniczna, wojskowa, gospodarcza i komunikacja ${ }^{71}$. Trudno jednak powiedzieć, na ile propozycja ta stanowiła realne, na ile taktyczne zagranie, mające pokazać gotowość do kompromisu. W Warszawie wiedziano bowiem doskonale, że wszelkie tego rodzaju rozwiązania były odrzucane przez władze w Kownie. Okazał się to też zresztą, jak się wydaje, łabędzi śpiew samej idei federacyjnej. Ale na jej bazie w przyszłości wyłoniły się koncepcje „prometeizmu” i „międzymorza”72.

Koncepcje federacyjne wciąż pojawiały się w publicystyce piłsudczykowskiej, m.in. na łamach „Drogi”33. Ich echa jeszcze wielokrotnie pobrzmiewały, np. w uchwale Walnego Zjazdu PSL „Wyzwolenie” z marca $1925 \mathrm{r}^{74}$ Socjaliści również przypominali sobie o nich w momentach kryzysów. W 1923 r. proponowano więc federację z krajami bałtyckimi i Czechosłowacją jako przeciwwagę dla mocarstw, po Locarno, rozszerzając ją jeszcze o Węgry, Rumunię i Jugosławię. Nestor polskich socjalistów Limanowski, niestrudzony zwolennik samej federacji jako sposobu organizacji życia międzynarodowego, pisał w „Robotniku” o federacji Polaków, Litwinów, Białorusinów i Ukraińców jako wspólnocie równych podmiotów. Po wybuchu Wielkiego Kryzysu socjaliści porzucili ideę federacyjną na rzecz integracji całej Europy ${ }^{75}$. W latach trzydziestych o koncepcjach federacji z Litwą, Białorusią czy Ukrainą w zasadzie zapomniano, nawet wśród piłsudczyków. Wspominano ją w środowiskach konserwatywnych. Jan Bobrzyński przedstawiał wizję trójczłonowego mocarstwa Polaków, Litwinów i Ukraińców, realizującego zmienioną ideę jagiellońską. Młody konserwatysta z kręgu „Buntu Młodych” Adolf Bocheński snuł marzenie o federacji polsko-ukraińskiej ${ }^{76}$.

Podsumowując powyższe rozważania, należy zauważyć, że fala koncepcji federacyjnej, której największe natężenie możemy obserwować w burzliwych latach 1917-1919, szybko opadła. Jej zmierzch spowodował traktat ryski, ale już w drugiej połowie 1920 r. niewielu było promotorów tych idei. Jeśli chodzi o zasięg terytorialny, na ogół wiązały one z Polską ziemie litewskie i białoruskie dawnego

${ }^{71}$ Szerzej zob. ibidem, s. 229; J. Bardach, Projekty organizacji kantonalnej Litwy oraz konfederacji polsko-litewskiej z 1921 roku, w: idem, O dawnej..., s. 280-292; M. Kornat, op. cit., s. 404-408.

72 J. Lewandowski, Imperializm słabości..., s. 155.

${ }^{73}$ J. Faryś, op. cit., s. 107-108.

74 J. Jachymek, op. cit., s. 147; B. Stoczewska, Ukraina..., s. 314-315.

75 J. Juchnowski, Federalizm i integracja..., s. 202-204; M. Boruta, op. cit., s. 206. Eugeniusz Koko twierdził, że po $1921 \mathrm{r}$. idee federacji nadal były podtrzymywane przez niektórych publicystów PPS, ale spotykały się z dużymi oporami, zwłaszcza w organizacjach terenowych. E. Koko, op. cit., s. 146.

76 A. Bocheński, Między Niemcami a Rosja, Warszawa 1937, s. 78-85; R. Wapiński, Świadomość polityczna..., s. 284-285; W. Mich, Publicystyka polityczna „Naszej Przyszłości” 1930-1939, Lublin 2009, s. 157. 
Wielkiego Księstwa Litewskiego (bez terenów o zdecydowanej przewadze polskiej). Zasadniczo dominujący wśród proponowanych form był więc twór trialistyczny (Polska, Litwa i Białoruś), jakkolwiek padały też propozycje oparte na większej liczbie części składowych (kantonalno-federacyjne). Rzadziej dołączano doń jeszcze ziemie ukraińskie (właściwie tylko dawną rosyjską ich część, Galicję Wschodnią pozostawiając przy Polsce). Pojawiały się też idee "bloku narodów” sąsiadujących z Rosją od zachodu, od Finlandii po Ukrainę, a nawet po południe Europy Środkowo-Wschodniej, mającego jednak, jak się wydaje, raczej luźniejszy charakter konfederacji (związku państw). Próbując odpowiedzieć na pytanie sformułowane na początku artykułu, najistotniejszą zmianą w myśleniu federalistycznym po 1918 r. w stosunku do okresu wcześniejszego było odejście od prostego, „mechanicznego" odtworzenia unii Korony i Litwy z czasów I Rzeczypospolitej na rzecz "nowoczesnej federacji” (cokolwiek rozumiano pod tym terminem) czy „Związku państw”. Novum stanowiło też rozwiązanie kantonalne na wzór szwajcarski czy podobne w treści Stany Zjednoczone Litwy. Częściej myślano o szerszej federacji państw od Finlandii po Jugosławię, a nawet o Zjednoczonych Stanach Europy ${ }^{77}$.

Podstawowym powodem formowania powyższych koncepcji było przekonanie o potrzebie stworzenia silnego organizmu państwowego, który oprze się imperializmowi rosyjskiemu, jak też niemieckiemu ${ }^{78}$. Sama idea miała więc charakter raczej obronny, nie ekspansjonistyczny, jak zarzucała jej dawna peerelowska historiografia. Towarzyszyło temu nie mniej istotne przeświadczenie, że tylko funkcjonowanie $\mathrm{w}$ jednym organizmie państwowym pozwoli przejść do porządku nad sporami terytorialnymi, głównie o przynależność Wilna i Lwowa ${ }^{79}$. Stało za tym również przekonanie, iż małe państwa powstałe u zachodnich granic Rosji długo nie obronią swojej niepodległości przed imperialnymi zakusami rosyjskimi. Wreszcie chodziło o uniknięcie oskarżeń Polaków o imperializm, znajdujących szeroki posłuch na zachodzie Europy ${ }^{80}$. Marek Kornat podkreślił również pragmatyczny charakter idei - narzędzia umożliwiającego międzynarodowy awans Polski jako sprawczej siły „urządzenia Europy Wschodniej”"1. Gennadii Korolow zauważył, że idee federacyjne były tylko elementem kształtowania się państw narodowych, modelami konsolidowania „narodowych przestrzeni”. Polskie koncepcje

77 Stara idea socjalistów, która pojawiała się u działaczy II Międzynarodówki. E. Koko, op. cit., s. 126.

78 Zob. A. Skwarczyński, Nowy rzad, „Rząd i Wojsko” (21 XII 1919), nr 48/49. Jak pisał w 1919 r. Oskar Halecki: „Polska etnograficzna, tak niewielka, nie zdoła zastąpić dawnej Rosji dla zaszachowania Niemiec od wschodu, zaczęto się coraz bardziej utwierdzać w przekonaniu, że tę właśnie dawną Rosję w tym celu odbudować należy. Rola międzynarodowa Polski zeszłaby tym samym do minimum, bo z chwilą upadku komunistów w Rosji przestałaby być komukolwiek potrzebna. Zwrot mogłoby tutaj spowodować tylko porozumienie Polski z Litwą i Rusią”, cyt. za: M. Kornat, op. cit., s. 387.

79 J. Lewandowski, Imperializm słabości..., s. 44; E. Koko, op. cit., s. 146.

80 M.K. Dziewanowski, op. cit., s. 350.

${ }^{81}$ M. Kornat, op. cit., s. 409. 
$\mathrm{w}$ tej sferze potraktował raczej jako narzędzia polityki wschodniej, a nie prawdziwy program kształtowania federalnej państwowości ${ }^{82}$. W przypadku koncepcji formowanych na prawicy można domniemywać, że chodziło także o utrzymanie na kresach dominacji mniejszościowego żywiołu polskiego.

Przedstawione powyżej idee federacyjne, poza nielicznymi wyjątkami, charakteryzowały się daleko idącą ogólnością. Miały wręcz mgławicowy charakter. Nie proponowano na ogół konkretnych rozwiązań ustrojowych (np. organizacji parlamentu i sposobu jego wybierania, podziału kompetencji pomiędzy składowe federacji itd.), nie mówiąc już o innych obszarach. W przypadku wielu pomysłów trudno nawet określić, czy ich autorom chodziło o ściślejszy związek (a więc stricte federacyjny), czy być może luźniejszą konfederację już istniejących organizmów państwowych (związek państw ${ }^{83}$ ). Wzmagało to nieufność adresatów tych propozycji, podejrzewających $\mathrm{w}$ nich chęć zamaskowania polskiej dominacji.

Słabościami tych wszystkich koncepcji było oderwanie od ówczesnych realiów, przede wszystkim dążeń narodów kresowych do stworzenia własnego państwa narodowego. Łatwo zauważyć, że wizje federacyjne formułowali sami tylko Polacy czy tzw. krajowcy, w dodatku nie próbowano na ogół przekonywać doń elit narodów, które miałyby wejść w skład takiej federacji. Charakterystyczne, że wśród Białorusinów po $1918 \mathrm{r}$. pojawiały się koncepcje reaktywowania w jakiejś formie Wielkiego Księstwa Litewskiego w postaci federacji białorusko-litewskiej czy także z udziałem Łotyszy i Ukraińców. Jednakże w tych planach nie było miejsca dla Polski ${ }^{84}$. Im śmielsze wizje prezentowano $\mathrm{w}$ polskiej przestrzeni publicznej, tym mniej zaprzątano sobie głowę szukaniem sojuszników. Stało za tym być może nieco naiwne przekonanie, zdradzające wyraźnie paternalistyczne podejście, że przecież z powodu rosyjskiego zagrożenia Litwini i Białorusini czy Ukraińcy nie mają innego wyjścia, jak oprzeć się na Polsce ${ }^{85}$. W sporej mierze (może z wyjątkiem socjalistów) wiązało się to $\mathrm{z}$ ich instrumentalnym traktowaniem jako narzędzia przeciwko Rosji. Niewątpliwie mamy więc do czynienia z typowym wishful thinking. Tymczasem owe narody nie wierzyły w zapewnienia o oparciu takiego związku na równości i braterstwie. Obawiały się, nie bez słuszności przecież, dominacji żywiołu polskiego (zdecydowanie silniejszego ekonomicznie), a nawet groźby

${ }^{82}$ G. Korolov, „Dwie Europy Środkowe” Oskara Haleckiego w „cieniu imperializmów”, „Kwartalnik Historyczny" (2017), nr 4, s. 687.

${ }^{83}$ Zdaniem Derugi socjaliści używali tego terminu tylko dlatego, by nie drażnić endeków słowem „federacja”. A. Deruga, Polityka wschodnia..., s. 30.

${ }^{84}$ D. Michaluk, Białoruska Republika Ludowa 1918-1920. U podstaw białoruskiej państwowości, Toruń 2010, s. 261.

${ }^{85} \mathrm{~K}$. Buchowski, Litwomani i polonizatorzy. Mity, wzajemne postrzeganie i stereotypy $w$ stosunkach polsko-litewskich w pierwszej połowie XX wieku, Białystok 2006, s. 169. Jak pisał Niedziałkowski: „Jeśli Litwa ma istnieć, to musi się oprzeć o Polskę, jeśli Białoruś ma się rozwinąć w świadomy sobie organizm narodowy, to musi się oprzeć o Polskę. Jeśli Ukraina ma się dźwignąć do własnej państwowości, to musi szukać oparcia o Polskę", cyt. za: M. Śliwa, Kwestia narodowościowa..., s. 109. 
wynarodowienia. Potwierdzało to postępowanie władz wojskowych czy polskiej administracji na zajętych terenach ${ }^{86}$. Warto też zauważyć, że polskie projekty odwoływały się do wspólnej przeszłości, która była inaczej postrzegana przez potencjalnych współpartnerów federacji. W dobie rozbuchanych nacjonalizmów i narastających konfliktów etnicznych uważano je za utopijne i anachroniczne. Kluczowa dla fiaska pomysłów federacyjnych była zdecydowana odmowa ze strony Litwinów ${ }^{87}$. Chociaż wśród Białorusinów znaleźli się zwolennicy tej idei, skupieni w Radzie Najwyższej, nie liczyli się już tak bardzo w polskich spekulacjach z uwagi na słabość ich ruchu narodowego oraz nikłe poparcie w społeczeństwie ${ }^{88}$.

Innym powodem niepowodzenia tych pomysłów był brak szerszej dlań akceptacji w kraju. Mimo wysiłków publicystów nie udało się przekonać większości społeczeństwa, które nie dostrzegało korzyści idei federacyjnej, optując za prostą inkorporacją ziem dawnej Rzeczypospolitej ${ }^{89}$. W tej sytuacji nie dziwi, że szybko nierealność wszelkich wizji federacyjnych stała się oczywista nawet dla ich zwolenników i wkrótce popadły one w niemal całkowite zapomnienie, trwające aż do końca II Rzeczypospolitej.

\section{Federation Ideas in the Second Polish Republic}

\section{Abstract}

Between 1917 and 1921, there were numerous federation concepts in Poland formulated. Most of them were defined by the so-called Belvedere Camp associated with Józef Piłsudski, but also by other circles, including some conservatives. Federationist ideas were put forward mainly in the press, but they were also presented in the Legislative Sejm of the period. They responded to the growing national awareness of Lithuanians, Byelorussians, and Ukrainians in those areas of the Polish territory where Poles represented a significant and economically dominant minority. They usually postulated creating a federal state of three countries: Poland, Lithuania,

86 Zob. E. Mironowicz, Białorusini wobec państwa polskiego 1918-1925, „Białoruskie Zeszyty Historyczne" (1994), z. 1, s. 24-25; idem, Białorusini w polityce piłsudczyków w latach dwudziestych, „Białoruskie Zeszyty Historyczne” (2005), z. 23, s. 35; J. Gierowska-Kałłaur, Zarząd Cywilny Ziem Wschodnich (19 lutego 1919 - 9 września 1920), Warszawa 2003.

87 Zob. np.: R. Wapiński, Świadomość polityczna..., s. 212; D. Staliūnas, Nowoczesna Litwa - Czy istniała alternatywa dla modelu państwa narodowego?, „Kwartalnik Historyczny” (2018), nr 2, s. 420-421. Stąd też nawet wśród zwolenników federacji na Wileńszczyźnie (ks. Józef Gądzki, Marian Świechowski czy Władysław Wielhorski) czy na łamach „Wschodu Polski” pojawiały się propozycje najazdu na Kowno, a więc siłowego narzucenia rozwiązań federacyjnych. K. Buchowski, op. cit., s. 161-163.

${ }^{88}$ J. Jurkiewicz op. cit., s. 211; E. Mironowicz, Białorusini wobec państwa polskiego..., s. 24; A. Nowak, op. cit., s. 332; A. Czarniakiewicz, op. cit., s. 26-90.

${ }^{89}$ J. Lewandowski, Imperializm słabości..., s. 48; R. Wapiński, Świadomość polityczna..., s. 200-205. Bogusław Miedziński zarzucał lewicy niepodległościowej, że poza kilkoma, kilkunastoma ludźmi nie wkładał w tę sprawę całego serca i przekonania. B. Miedziński, op. cit., s. 11. Por. R. Wapiński, Świadomość polityczna..., s. 207. 
and Belarus. There were also proposals to include other, nationally homogeneous regions - this was the so-called cantonal solution.

Contrary to the view that has become well established in historiography, most projects of such a federation did not include Ukraine. There were also ideas of a wider union of nations from Finland to the Black Sea. The purpose was to create a solid federal state capable of withstanding the threat from Germany and Russia.

However, the federation idea did not enjoy the support of Polish society, which favoured the direct incorporation of the eastern territories into the Polish state. Also, there were few supporters of the federalist ideas among Byelorussians, Lithuanians, and Ukrainians, as they feared Polish domination. The Riga Peace Treaty ended the federation plans, dividing the Byelorussian and Lithuanian lands between Poland and Soviet Russia.

\section{Федеративные концепции во Второй Речи Посполитой}

\section{Аннотация}

В 1917-1921 годах в Польше имели дело с множеством федеративных концепций. Большинство из них было создано кругами Бельведерского лагеря, связанными с Юзефом Пилсудским, но и другими кругами, включая некоторых консерваторов. Федеративные идеи формировались в основном в журналистике, а также артикулировались на форуме Учредительного сейма. Они являлись ответом на растущее национальное самосознание литовцев, белорусов и украинцев на территориях, где поляки были значительным и экономически доминирующим меньшинством. Обычно они предполагали создание федеративного государства, состоящего из трех частей: Польши, Литвы и Белоруссии. Были также предложения о большем числе составных частей, национально однородных регионов - т.н. кантональное решение. Вопреки устоявшемуся в историографии мнению, большинство проектов такой федерации не включали в нее Украину. Возникали также идеи более широкого союза наций от Финляндии до Черного моря. Хотели создать сильное государство, способное противостоять угрозе со стороны Германии и России.

Однако федеративные идеи не нашли поддержки в польском обществе, которое выступало за прямое присоединение восточных территорий к польскому государству. Также среди белорусов, литовцев и украинцев хватало сторонников федеративных решений, ибо они опасались польского господства. Рижский мирный договор положил конец федеративным планам, разделив белорусские и литовские земли между Польшей и Советской Россией.

\section{Bibliografia}

\section{Źródła drukowane}

Bocheński A., Między Niemcami a Rosją, Warszawa 1937.

Charaszkiewicz E., Przebudowa Wschodu Europy. Materiały do polityki wschodniej Józefa Pitsudskiego w latach 1893-1921, „Niepodległość” 5 (1955), s. 125-167.

Okulicz K., Ostatni akt dramatu Józefa Piłsudskiego (1920-1922), „Zeszyty Historyczne” (1966), nr 9, s. 7-45.

Piłsudska A., Wspomnienia, Londyn 1960. 
Piłsudski J., Pisma zbiorowe, t. 5-6, Warszawa 1937.

Rataj M., Pamiętniki (1918-1927), Warszawa 1965.

Rok 1920. Wojna polsko-radziecka we wspomnieniach i innych dokumentach, wybór i oprac.

J. Borkowski, Warszawa 1990.

Sprawozdania Stenograficzne Sejmu Ustawodawczego.

Sprawy polskie na konferencji pokojowej w Paryżu w 1919. Dokumenty i materiały, red. R. Bierzanek, J. Kukułka, t. 1, Warszawa 1965.

\section{Opracowania}

Balcerak W., Koncepcje integracyjne w polskiej polityce zagranicznej 1918-1939, „Dzieje Najnowsze" (1970), nr 1, s. 31-56.

Bardach J., O dawnej i niedawnej Litwie, Poznań 1988.

Bączkowski W., U źródeł polskiej idei federacyjnej, Jerozolima 1945.

Bokajło W., Historyczne tło polskiego federalizmu, w: Federalizm. Teorie i koncepcje, red. W. Bokajło, Wrocław 1998, s. 171-201.

Boruta M., Wolni z wolnymi, równi z równymi. Polska i Polacy o niepodległości wschodnich sąsiadów Rzeczypospolitej, Kraków 2002.

Buchowski K., Litwomani i polonizatorzy. Mity, wzajemne postrzeganie i stereotypy w stosunkach polsko-litewskich w pierwszej połowie XX wieku, Białystok 2006.

Cisek J., Kilka uwag o myśli federacyjnej Józefa Piłsudskiego, w: Międzymorze. Polska i kraje Europy Środkowo-Wschodniej XIX-XX wiek, Warszawa 1995, s. 91-99.

Czapiewski E., Koncepcje polityki zagranicznej konserwatystów polskich w latach 1918-1926, Wrocław 1988.

Czarniakiewicz A., Kształtowanie się ośrodka polonofilskiego w białoruskim ruchu narodowym (listopad 1918 - grudzień 1919), „Białoruskie Zeszyty Historyczne” (2008), z. 29, s. 23-90.

Daszyk K., Idea Europy wolnych i zjednoczonych narodów w polskiej myśli politycznej XIX w., w: Europa unii i federacji. Idea jedności narodów i państw od średniowiecza do czasów współczesnych, red. K. Ślusarek, Kraków 2004, s. 231-258.

Deruga A., O federalizmie i polityce wschodniej obozu belwederskiego, „Przegląd Historyczny” (1964), z. 2, s. 317-330.

Deruga A., Polityka wschodnia Polski wobec ziem Litwy, Białorusi i Ukrainy (1918-1919), Warszawa 1969.

Dziewanowski M.K., Joseph Piłsudski. A European Federalist, 1918-1922, Stanford 1969.

Faryś J., Między Moskwa a Berlinem. Wizje polskiej polityki zagranicznej 1918-1939, Szczecin-Warszawa 2019.

Gierowska-Kałłaur J., Straż Kresowa wobec kwestii białoruskiej. Deklaracje i praktyka, „Studia z Dziejów Rosji i Europy Środkowo-Wschodniej” 44 (2009), s. 21-62.

Gierowska-Kałłaur J., Zarząd Cywilny Ziem Wschodnich (19 lutego 1919 - 9 września 1920), Warszawa 2003.

Grygajtis K., Polskie idee federacyjne i ich realizacja w XIX $i$ XX wieku, Częstochowa 2001.

Hauser P., Federacyjna wizja Rzeczypospolitej w poglądach Józefa Piłsudskiego i próba jej urzeczywistnienia w latach 1918-1921, w: Polska i Ukraina. Sojusz z 1920 roku i jego następstwa, red. Z. Karpus, W. Rezmer, E. Wiszka, Toruń 1997, s. 17-39.

Jachymek J., Rozwiązanie problemu mniejszości narodowych. Ruch ludowy (1918-1939), w: Między rzeczywistościa polityczna a światem iluzji. Rozwiązanie problemu mniejszości narodowych w polskiej myśli politycznej XX wieku, red. J. Jachymek, W. Paruch, Lublin 2002, s. $141-159$.

Jakubowski W., Jajecznik K., Polska debata ustrojowa w latach 1917-1921, Warszawa 2010. 
Juchnowski J., Federalizm i integracja europejska w myśli politycznej socjalistów polskich (19221939), w: Federalizm. Teorie i koncepcje, red. W. Bokajło, Wrocław 1998, s. 202-213.

Juchnowski J., Federalizm w polskiej myśli politycznej XX wieku, w: Polacy - Polska - Europa. Interpretacje idei politycznych, red. T. Godlewski, W. Jurkiewicz, Bydgoszcz 2002, s. 209222.

Juchnowski J., Juchnowski S., Koncepcje unijno-federalistyczne w polskiej myśli politycznej na tle integracyjnych idei europejskich, „Społeczeństwo i Polityka” (2019), nr 3 (60), s. 89-114.

Jurkiewicz J., Rozwój polskiej myśli politycznej na Litwie i Białorusi w latach 1905-1922, Poznań 1983.

Koko E., W nadziei na zgodę. Polski ruch socjalistyczny wobec kwestii narodowościowej w Polsce (1918-1939), Gdańsk 1995.

Kornat M., Z projektów federacyjnych w polskiej myśli politycznej (1917-1921), w: O ziemię nasza, nie wasza. Ideowe aspekty procesów narodowotwórczych w Europie Środkowej $i$ Wschodniej, red. Ł. Adamski, Warszawa 2017, s. 361-409.

Korolov G., „Dwie Europy Środkowe” Oskara Haleckiego w „cieniu imperializmów”, „Kwartalnik Historyczny" (2017), nr 4, s. 677-698.

Korzeniewski B., Wyprawa kijowska w polskiej propagandzie prasowej, „Przegląd Humanistyczny" (2006), nr 1, s. 83-98.

Krajowość - tradycje zgody narodów w dobie nacjonalizmów, red. J. Jurkiewicz, Poznań 1999.

Kubis B., Polska myśl polityczna wobec idei integrowania Europy w drugiej połowie XIX wieku i początkach XX, w: Europejskie inspiracje myśli politycznej w Polsce od XIX do XXI wieku, red. E. Maj, A. Dawidowicz, Ł. Lewkowicz, A. Szwed, Lublin 2013, s. 17-30.

Lewandowski J., Federalizm: Litwa i Białoruś w polityce obozu belwederskiego (XI 1918 IV 1920), Warszawa 1962.

Lewandowski J., Imperializm słabości. Kształtowanie się koncepcji polityki wschodniej piłsudczyków 1921-1926, Warszawa 1967.

Lewandowski J., Kwestia ukrainska w II Rzeczypospolitej, „Aneks” (1982), nr 28, s. 97-122.

Łossowski P., Po tej i tamtej stronie Niemna. Stosunki polsko-litewskie 1883-1939, Warszawa 1985.

Łossowski P., Stosunki polsko-litewskie w latach 1918-1920, Warszawa 1966.

Łysek W., The Federal Idea in Poland in the Interwar Period: Idealism or Pragmatism?, „Politeja” (2017), nr 6 (51), s. 95-115.

Maciejewski M., Wspólna Europa w polskich koncepcjach politycznych czasów nowożytnych, w: Dialog idei w Europie w XX i XXI wieku, red. E. Ponczek, A. Sepkowski, Toruń 2011, s. $95-122$.

Mackiewicz M., Koncepcje społeczno-polityczne grupy wileńskich krajowców-demokratów w latach 1906-1911, „Folia Iuridica Universitatis Wratislaviensis” (2013), nr 1, s. 101-113.

Mich W., Publicystyka polityczna „Naszej Przyszłości” 1930-1939, Lublin 2009.

Michałowski S., Mniejszości narodowe w myśli politycznej socjalistów polskich (1892-1939), w: Między rzeczywistościa polityczna a światem iluzji. Rozwiązanie problemu mniejszości narodowych w polskiej myśli politycznej XX wieku, red. J. Jachymek, W. Paruch, Lublin 2002, s. 161-179.

Miedziński B., Polityka wschodnia Piłsudskiego, „Zeszyty Historyczne” (1975), z. 31, s. 3-45.

Mikulicz S., Prometeizm w polityce II Rzeczypospolitej, Warszawa 1971.

Mironowicz E., Białorusini w polityce piłsudczyków w latach dwudziestych, „Białoruskie Zeszyty Historyczne" (2005), z. 23, s. 34-58.

Mironowicz E., Białorusini wobec państwa polskiego 1918-1925, „Białoruskie Zeszyty Historyczne" (1994), z. 1, s. 20-28.

Nowak A., Polska i trzy Rosje. Studium polityki wschodniej Józefa Piłsudskiego (do kwietnia 1920), Kraków 2001. 
Okulewicz P., Koncepcja „Międzymorza” w myśli i praktyce politycznej obozu Józefa Piłsudskiego $w$ latach 1918-1926, Poznań 2001.

Pisuliński J., Czy Piłsudski był federalista? - dylematy polskiej historiografii, „Biuletyn Ukrainoznawczy" (2005), nr 11, s. 111-126.

Pisuliński J., Nie tylko Petlura. Kwestia ukraińska w polskiej polityce zagranicznej $w$ latach 1918-1923, Wrocław 2004.

Staliūnas D., Nowoczesna Litwa - Czy istniała alternatywa dla modelu państwa narodowego?, „Kwartalnik Historyczny” (2018), nr 2, s. 403-425.

Stoczewska B., Litwa, Białoruś, Ukraina w myśli politycznej Leona Wasilewskiego, Warszawa 2009.

Stoczewska B., Ukraina i Ukraińcy w polskiej myśli politycznej od końca XIX wieku do wybuchu II wojny światowej, Kraków 2013.

Śliwa M., Federalizm i autonomia narodowościowa w myśli Mieczysława Niedziałkowskiego, „Czasopismo Prawno-Historyczne” 30 (1978), z. 2, s. 139-153.

Śliwa M., Kwestia narodowościowa $w$ programach $i$ publicystyce socjalistów polskich $w$ okresie Drugiej Rzeczypospolitej, „Dzieje Najnowsze” (1983), nr 1-2, s. 107-128.

Wandycz P.S., Piłsudski a federalizm, „Rocznik Instytutu Europy Środkowo-Wschodniej” 10 (2012), z. 4, s. 45-54.

Wandycz P.S., Polscy prekursorzy federalizmu, w: idem, O federalizmie i emigracji. Reminiscencje o rzeczach istotnych $i$ błahych, Lublin 2003, s. 97-113.

Wapiński R., Polska i małe ojczyzny Polaków. Z dziejów kształtowania się świadomości narodowej XIX i XX wieku po wybuch II wojny światowej, Wrocław-Warszawa-Kraków 1994.

Wapiński R., Polska myśl polityczna XIX i XX wieku, Gdańsk 1997.

Wapiński R., Świadomość polityczna w Drugiej Rzeczypospolitej, Łódź 1989.

Werschler I., Z dziejów obozu belwederskiego. Tadeusz Hołówko życie i działalność, Warszawa 1984.

Wojtaszak A., Koncepcje federacyjne Leona Wasilewskiego, „Nowa Krytyka” (2016), nr 37, s. 247-264.

Zaporowski Z., Federalizm Józefa Piłsudskiego (1918-1922), w: Świat wokół Rzeczypospolitej. Problematyka zagraniczna w polskiej myśli politycznej w pierwszej połowie XX wieku, red. W. Paruch, K. Trembicka, Lublin 2007, s. 179-188.

Zweiffel Ł., „O program polski na Wschodzie” - koncepcja federacyjna w publicystyce socjalistycznej lat 1919-1920, „Rocznik Wschodni” (2006/2007), nr 12, s. 232-236.

Zweiffel Ł., Państwa bałtyckie wobec koncepcji federacyjnej PPS, „Rocznik Wschodni” (2004), nr 10, s. 291-295.

Корольов Г., Федеративні проекти в иентрально-східній Європі від ідеологічної утопї до реальної політики (1815-1921 рр.), Київ 2019.

Jan Pisuliński, dr hab., prof. UR, kierownik Zakładu Historii Najnowszej Instytutu Historii Uniwersytetu Rzeszowskiego. Zajmuje się stosunkami polsko-ukraińskimi w XX stuleciu (pisulinski@wp.pl).

Jan Pisuliński, PhD with habilitation, prof. of the University of Rzeszów, head of the Department of Contemporary History at the Institute of History, University of Rzeszów; his academic interests cover the Polish-Ukrainian relations in the 20th century (pisulinski@wp.pl). 